\title{
Cystadenocarcinoma simulating hemangiosarcoma of the salivary gland in dog: case report
}

\author{
[Cistoadenocarcinoma simulando hemangiossarcoma de glândula salivar em cão: relato de caso]

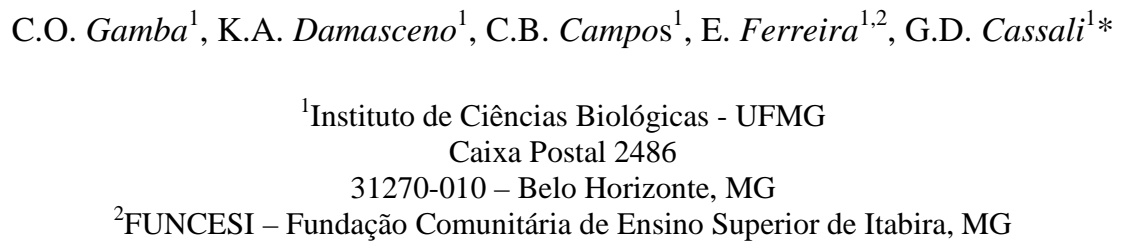

\begin{abstract}
Cystadenocarcinoma is regarded as a rare adenocarcinoma variant in animals. This work reports the case of an 8-year-old female Poodle dog with salivary gland cystadenocarcinoma with morphological characteristics similar to a hemangiosarcoma. Histopathological analysis showed a tumor mass with cystic formations containing a large amount of red blood cells. In order to distinguish these two entities, periodic acid Schiff (PAS) staining and immunohistochemical analysis were carried out with the use of cytokeratin AE1/AE3 (CK) and CD31-specific antibodies. Neoplastic cells were PAS-negative, CKpositive and CD31-negative confirming their epithelial origin. Based on the findings, the diagnosis of high grade cystadenocarcinoma was established.
\end{abstract}

Keywords: bitch, salivary gland, CD31, neoplastic cells

\section{RESUMO}

O cistoadenocarcinoma é considerado uma variante do adenocarcinoma de rara ocorrência em animais. Este trabalho relata um caso de cadela Poodle de oito anos, portadora de cistoadenocarcinoma de glândula salivar com características morfológicas semelhantes a de hemangiossarcoma. Na análise histopatológica observou-se uma massa tumoral com formações císticas contendo grande quantidade de hemácias. Para a diferenciação entre as duas entidades realizou-se coloração pelo ácido periódico de Schiff (PAS) e análise imuno-histoquímica com a utilização de anticorpos para citoqueratina AE1/AE3 (CK) e CD31. As células neoplásicas apresentaram-se PAS negativas, CK positivas e CD31 negativas demonstrando a origem epitelial. Com base nos achados firmou-se o diagnóstico de cistoadenocarcinoma de alto grau.

Palavras-chave: cadela, glândula salivar, CD31, células neoplásicas

\section{INTRODUCTION}

Salivary gland tumors are not frequent in dogs and cats, representing about $0.3 \%$ of salivary gland diseases (Spangler and Culbertson, 1991). They usually affect old animals, with no differences between breed or sex. The most affected salivary gland is the parotid (Moulton, 1978), and adenocarcinomas are the histological type most frequently found in dogs (Hammer et al., 2001). Cystadenocarcinoma was reported for the first time as a rare adenocarcinoma variant in animals (Head et al., 2002). This tumor has been widely described in human medicine (Shrestha et al., 1994; Johnston et al., 2006; Aloudah et al., 2008; Gallego et al., 2008) and is macroscopically characterized by the formation of masses with varied colors and slow growth which may present cystic areas with mucous content and discrete necrosis (Johnston et al.,

Recebido em 13 de outubro de 2010

Aceito em 18 de maio de 2011

*Autor para correspondência (corresponding author)

Email: cassalig@icb.ufmg.br 
2006; Gallego et al., 2008). Microscopically, it refers to a neoplasm composed of several cysts, which may present papillary projections and sometimes red blood cells inside the cysts (Johnston et al., 2006; Gallego et al., 2008). Most of these tumors produce a mucoid substance, and histochemical techniques such as Periodic Acid Schiff (PAS) or Mayer's Mucicarmine stain (Pollet et al., 1997) evidence this type of material.

When poorly differentiated, malignant tumors characterized by vessel formation, as hemangiosarcomas and lymphangiosarcomas, require the use of an additional tool to help distinguish them from tumors, which mimic the formation of vascular spaces, such as cystadenocarcinomas. The immunohistochemical technique is extremely useful in the differential diagnosis of these histological types (Shrestha et al., 1994; Aloudah et al., 2008). Cytokeratins, intermediate filaments of normal and tumor epithelial cells, are reported in different histogenetic studies as markers used to evidentiate epithelial neoplasms and to identify micrometastases (Czerniecki et al., 1999; Los Monteros et al., 1999; Yeh and Mies, 2008). Furthermore, antibodies which identify proteins expressed by endothelial cells are used in order to characterize tumors of vascular origin (Lahat et al., 2010).

This work reports a case of salivary gland cystadenocarcinoma, describing its histomorphological and immunophenotypical characteristics and distinguishing it from a high histological grade hemangiosarcoma.

\section{CASE DESCRIPTION}

An 8-year-old female poodle dog presented an exophytic tumor growth, round and with a friable consistency, in the maxillary region of the left canine tooth. Surgical extirpation was performed as the treatment of choice. Macroscopic analysis showed that the tumor mass had an irregular surface, measuring about $4 \times 2 \times 2 \mathrm{~cm}$, with whitish areas of friable consistency and black dots. The cut surface presented a homogeneous solid aspect and white in color.

Fragments collected were fixed in neutral buffered $10 \%$ formalin solution and included in paraffin. Afterwards, $4 \mu \mathrm{m}$-histological sections were obtained from these fragments, stained with Hematoxylin and Eosin and PAS staining protocols. The mitotic index was performed evaluating 10 peripheral tumor areas with microscope (BX-41) magnification (40x) (Dutra et al., 2008).

Microscopical analysis showed cell proliferation in a cystic arrangement, delimited by cuboidal to flattened cells, arranged in one or two layers, filled with red blood cells and/or eosinophilic amorphous material (Fig. 1A). Cells are characterized by high nuclear pleomorphism, fragmented chromatin and an abundant eosinophilic cytoplasm. Furthermore, a cutaneous ulceration was observed, consisting predominantly of a polymorphonuclear inflammatory infiltrate. Cystic neoformations were PAS negative (Fig. 1D). The high mitotic index found (average of 4 mitoses/field), associated with the observation of intravascular tumor emboli and areas of stromal invasion, characterized a neoplasm with high histological grade (Fig. 1B and C).

A biotin-peroxidase system was used for immunohistochemical procedure with identification of the secondary antibody by the polymer (Advance HRP). Antigen retrieval was performed in water bath at $98^{\circ} \mathrm{C}$, with a citrate buffer solution $\mathrm{pH} \quad 6.0$ (Target Retrieval Solution) for 20 minutes. In order to block the endogenous peroxidase activity, slides were incubated with a solution of $\mathrm{H}_{2} \mathrm{O}_{2} 3 \%$ in methyl alcohol. Reagents were applied manualy, with 1 hour incubation for the primary antibody and 30 minutes for the other reagents, except for diaminobenzidine chromogen, incubated for 5 minutes. The monoclonal antibodies used were pan-cytokeratin (1:50, clone AE1/AE3 ) and CD31 (1:100, clone JC70A).

Immunohistochemical analysis showed cytoplasmic immunoreactivity for CD-31 in peritumoral vessels with a high staining intensity, considered an internal reaction control. However, neoplastic cells presented negative staining for the same protein (Fig.1E). High intensity cytoplasmic CK staining was observed in neoplastic cells, delimiting cystic neoformations (Fig. 1F). 

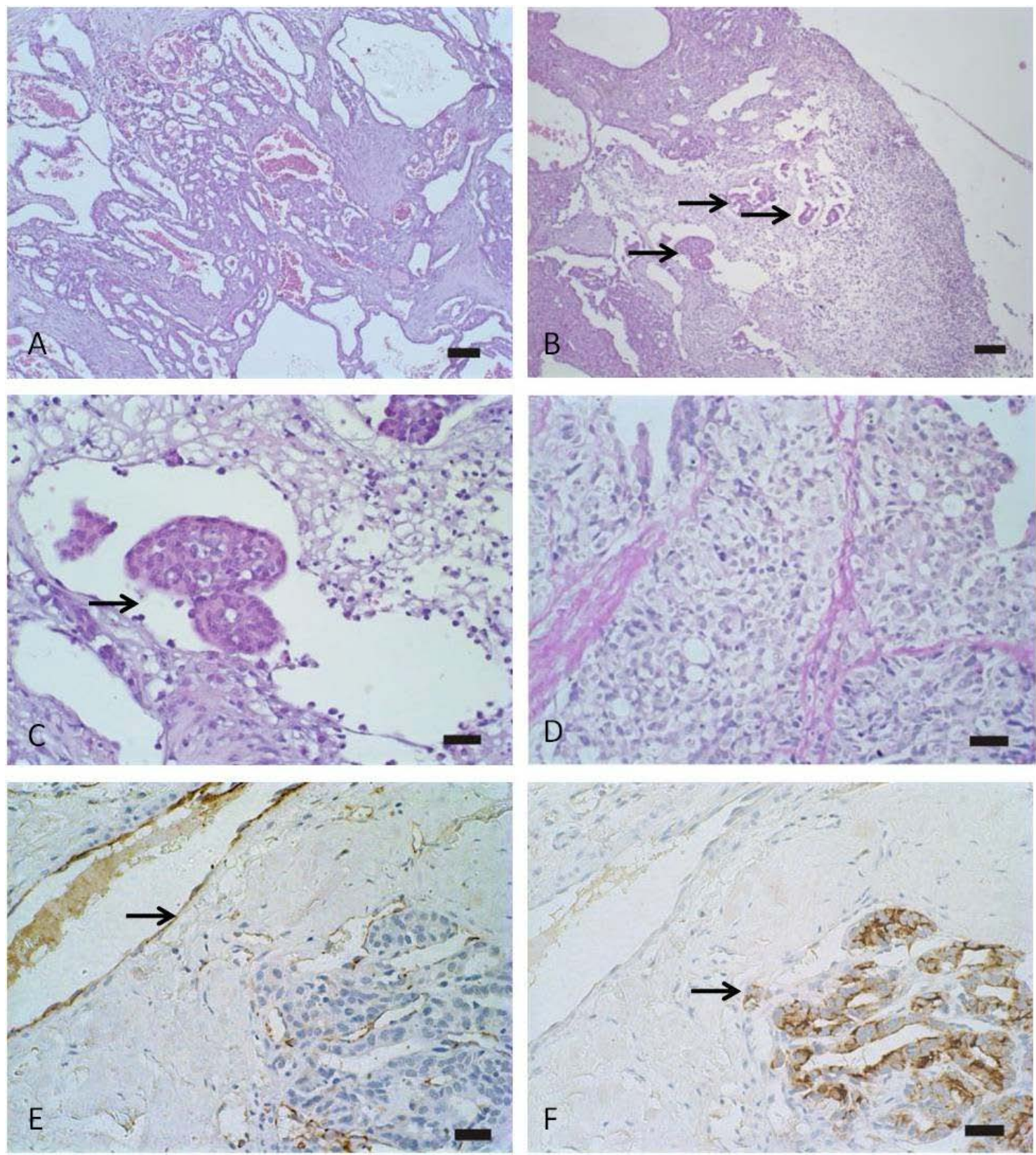

Figure 1. Dog oral mucosa: cystadenocarcinoma. (A). Epithelial cell proliferation in tubulopapillary pattern with dilated duct formation, sometimes containing red blood cells. H\&E Bar $=50 \mu \mathrm{m}$. (B) Neoplastic mass containing areas of vascular invasion (arrow). H\&E Bar $=50 \mu \mathrm{m}$. (C) Vascular tumor embols (arrow). H\&E Bar $=20 \mu \mathrm{m}$. (D) Neoplastic cells negative for PAS staining (arrow). Bar $=20 \mu \mathrm{m}$. (E) Positive vascular staining for CD-31 in positive control (normal vascular endothelium) (arrow). IHQ Bar $=20 \mu \mathrm{m}$. (F) Positive staining of neoplastic epithelial cells for CK AE1/AE3 (arrow). IHQ Bar = $20 \mu \mathrm{m}$.

\section{DISCUSSION}

Salivary gland cystadenocarcinoma is a salivary adenocarcinoma variant, rarely described in dogs. In 1975 a case of zygomatic adenocarcinoma (Buyukmihci et al., 1975) was reported, posteriorly considered a possible cystadenocarcinoma (Head et al., 2002) with macroscopical and microscopical characteristics similar to the present study's findings. In 
humans, due to its higher frequency, several papers have described cystadenocarcinoma regarding the histochemical and immunophenotypical characteristics (Pollet et al., 1997; Aloudah et al., 2008; Gallego et al., 2008).

In this case, the tumor was microscopically characterized by epithelial cell proliferation in a tubulopapillary pattern with the formation of cystic areas. These findings corroborate with descriptions in humans (Nakagawa et al., 2002; Johnston et al., 2006; Yamada et al., 2007).

In humans, high grade cystadenocarcinomas are described based on tumor behavior, including perineural infiltration, vascular or lymphatic invasion, infiltration of peritumoral connective tissue and metastasis in regional lymph node and high mitotic index (Pollett et al., 1997; Yamada et al., 2007). In the present report, infiltration of neoplastic cells in regional lymphatic vessels and high mitotic index was observed, confirming high histological tumor grade.

In cases with of poorly differenciated salivary gland tumors, the use of PAS staining is usually suggested to determine the histological character of the lesion, showing normal mucin production by tumor cells (Pollett et al., 1997; Militerno et al., 2005). However, this technique is not extremely effective, as cystadenocarcinomas with PAS-negative neoplastic cells have been reported in humans, as well as observed in this report (Kawahara et al., 2009).

In the present report, due to the presence of cystic formations containing a large amount of red blood cells, the histological analysis was followed by an immunohistochemical identification of epithelial and endothelial markers. A molecular study of hemangiosarcomas used CD-31 as a diagnostic tool in order to confirm malignant vascular tumors (Lahat et al., 2010). The same antibody may be used to discard a possible endothelial origin (hemangiosarcoma) (Cushing et al., 2010), as performed in the present study. Currently, several papers have used immunohistochemistry in order to characterize hemangiosarcomas (angiosarcomas), and distinguish them from tumors that mimic the formation of vascular spaces by means of particular antibodies. The positivity for cytokeratins was also reported in other studies (Pollett et al., 1997; Kawahara et al., 2009), where immunopheno typically characterize human salivary gland cystadenocarcinomas. Immunohistochemical evaluation showed that neoplastic cells were positive for pan-cytokeratin (clone AE1AE3) and negative for CD-31, showing an epithelial origin. Thus, immunohistochemistry has shown more accuracy, compared to histochemistry, when characterizing the neoplastic histogenesis.

\section{CONCLUSIONS}

Due to the fact that salivary cystadenocarcinomas are rare in domestic animals and present morphological heterogeneity, it is extremely important to report and show the use of tools such as immunohistochemistry to help to establish a differential diagnosis of histomorphologically similar tumor variants.

\section{ACKNOWLEDGMENTS}

This work has been financially supported by "Fundação de Amparo a Pesquisa de Minas Gerais" (FAPEMIG), "Conselho Nacional de Desenvolvimento Científico e Tecnológico” (CNPq) and "Coordenação de Aperfeiçoamento de Pessoal de Nível Superior” (CAPES), Brazil.

\section{REFERENCES}

ALOUDAH, N.M.; RADDAOUI, E.; ALDHAHRI, S. et al. Low-Grade papillary cystadenocarcinoma of the parotid gland: presentation of a case With cytological, histopathological, and immunohistochemical features and pertinent literature review. Diagn. Cytopathol., v.37, p.128131, 2008.

BUYUKMIHCI, N.; RUBIN, L.F.; HARVEY, C.E. Exophthalmos secondary to zigomatic adenocarinoma in a dog. J. Am. Vet. Med. Assoc., v.167, p.162-165, 1975

CUSHING, T.; BARNARD S.; FLEIS R. et al. Pseudoangiomatous squamous cell carcinoma in the oral cavity of a dog. J. Vet. Diagn. Invest., v.22, p.299-302, 2010.

CZERNIECKI, B.J.; SCHEFF, A.M.; CALLANS, L.S. et al. Immunohistochemistry with pancytokeratins improves the sensitivity of sentinel lymph node biopsy in patients with breast carcinoma. Cancer, v.85, p.1098-1103, 1999. 
DUTRA, A.P.; AZEVEDO JÚNIOR, G.M.; SCHMITT, F.C. et al. Assessment of cell proliferation and prognostic factors in canine mammary gland tumors. Arq. Bras. Med. Vet. Zootec., v.60, p.1403-1412, 2008.

GALLEGO, L.; JUNQUERA, L.; FRESNO, M.F. et al. Papillary cystadenoma and cystadenocarcinoma of salivary glands: two unusual entities. Med. Oral Patol. Oral Cir. Bucal, v.13, p.460-463, 2008.

HAMMER, A.; GETZY, D.; OGILVIE, G. et al. Salivary gland neoplasia in the dog and cat: survival times and prognostic factors. J. Am. Anim. Hosp. Assoc., v.37, p.478-482, 2001.

HEAD, K.W.; ELSE, R.W.; DUBIELZIG, R.R. Tumors of the alimentary tract. In: MEUTEN, D.J. (Ed.). Tumors in domestic animals. Iowa: WileyBlackwell, 2002. p.410-420.

JOHNSTON, N.J.; ROSE, D.S.C.; LUTTERLOCH, M.J. Cystadenocarcinoma of salivary gland presenting as a cystic lesion in the mandible. Oral Surg. Oral Med. Oral Pathol. Oral Radiol. Endod., v.101, p.201-204, 2006.

KAWAHARA, A.; HARADA, H.; MIHASHI H. et al. cytological features of cystadenocarcinoma in cyst fluid of the parotid gland: diagnostic pitfalls and literature review. Diagn. Cytopathol., v.38, p.377-381, 2009.

LAHAT, G.; DHUKA, A.R.; HALLEVI, H. et al. Angiosarcoma clinical and molecular insights. Ann. Surg., v.251, p.1098-1106, 2010.

LOS MONTEROS, A.E.; FERNÁNDEZ, A.; MILLÁN, M.Y. et al. Coordinate expression of cytokeratins 7 and 20 in feline and canine carcinomas. Vet. Pathol., v.36, p.179-190, 1999.
MILITERNO, G.; BAZZO, R.; MARCATO, P.S. Cytological diagnosis of mandibular salivary gland adenocarcinoma in a dog. J. Vet. Med. A. Physiol. Pathol. Clin. Med., v.52, p.514-516, 2005.

MOULTON, J.E. Tumors of the alimentary tract. In: MOULTON, J.E (Ed.) Tumors in domestic animals. Bekerley: University of California, 1978. p.249-252.

NAKAGAWA, T.; HATTORI, K.; IWATA, N. et al. Papillary cystadenocarcinoma arising from minor salivary glands in the anterior portion of the tongue: a case report. Auris Nasus Larynx, v.29, p.87-90, 2002.

POLLET, A.; PEREZ-ORDOÑEZ, B.; JORDAN, R.C.K. et al. High- grade papillary cystadenocarcinoma of the tongue. Histopathology, v.31, p.185-188, 1997.

SHRESTHA, P.; NAMBA, M.; YANG, L.J. et al. Papillary cystadenocarcinoma of salivary-glands an immunohistochemical study. Int. J. Oncol., v.4, p.587-597, 1994.

SPANGLER, W.L.; CULBERTSON, M.R. Salivary gland disease in dogs and cats. 245 cases (1985-1988). J. Am. Vet. Med. Assoc., v.198, p.465469, 1991.

YAMADA, S.; MATSUO, T.; BABA, N. et al. High-grade papillary cystadenocarcinoma of the sublingual gland: a case report. J. Oral. Maxillofac. Surg., v.65, p.1223-1227, 2007.

YEH, I.T.; MIES, C. Application of immunohistochemistry to breast lesions. Arch. Pathol. Lab. Med., v.132, p.349-358, 2008. 